\title{
SYNTHESIS OF INDOLES DERIVATIVES USING METAL FREE CATALYST IN ORGANIC REACTIONS
}

\author{
ORGANIK REAKSIYYONLARDA METAL IÇERMEYEN KATALIZZ̈̈R KULLANILARAK \\ INDOL TÜREVLERININ SENTEZI
}

\section{Hemlata DANGI ${ }^{1}$ (D), Ratnesh DAS ${ }^{1, *}$ (D), Sushil KASHAW ${ }^{2}$}

${ }^{1}$ Dr Harisingh Gour Central University Sagar, (M.P.), Deparment of Chemistry, 470003, India

${ }^{2}$ Dr Harisingh Gour Central University Sagar, (M.P.), Deparment of Pharmaceutical Sciences, 470003,

India

\begin{abstract}
Objective: Indole derivatives are one of the most flexible and common nitrogen-based skeletons and often used in the synthesis of numerous heterocyclic compounds, having biological or medicinal importance. Many indole derivatives have been isolated naturally from plants, fungi, and marine organisms and are highly important due to their pharmaceutical activities. They also play a significant character in polymer and dye industries as well as in the agriculture sector. There exists an immense potential for designing and methodology development for the synthesis of indole based heterocyclic scaffold structure with desire chemical and biomedical relevance.

Result and Discussion: In this present review, we outlined the recent applications of indoles in the onepot multi-component reaction using metal free catalysts for the preparation of various heterocyclic scaffolds and their corresponding biological activities are also discussed.

Keywords: Indole derivatives, metal free catalyst, one pot multi-component reaction, synthesis

ÖZ

Amaç: Indol türevleri azot bazlı iskeletlerden biridir ve biyolojik veya tıbbi önemi olan birçok heterosiklik bileşiğin sentezinde sıklıkla kullanılır. Birçok indol türevi bitkilerden, mantarlardan ve deniz organizmalarından doğal olarak izole edilmiştir ve farmasötik aktiviteleri nedeniyle oldukça önemlidirler. Ayrıca polimer ve boya endüstrilerinde ve tarım sektöründe de önemli rol oynarlar. Ístenen kimyasal ve biyomedikal özelliklere sahip indol bazl heterosiklik iskelet yapısının sentezi için tasarım ve metodoloji geliştirmeye ihtiyaç vardır.

Sonuç ve Tartışma: $B u$ derlemede, çeşitli heterosiklik yapı iskeletlerinin hazırlanması için metal içermeyen katalizörlerin kullanıldığı, tek kap çok bileşenli reaksiyonlarla indollerin son uygulamaları özetlenmiştir ve bunlara karşılık gelen biyolojik aktiviteler tartışılmıştır.
\end{abstract}

\footnotetext{
* Corresponding Author/Sorumlu Yazar: Ratnesh Das

e-mail / e-posta: ratneshdas1 @ gmail.com, Phone / Tel.: +917697834544
} 
Anahtar Kelimeler: Indol türevleri, metalsiz katalizör, sentez, tek potalı çok bileşenli reaksiyon

\section{INTRODUCTION}

Heterocyclic compounds have a high significance in the synthesis of medicinal and/as well organic synthesis and have a widespread application in the field of polymer, agriculture, medicine and in many industries. Multi-component reactions (MCRs) [1] are the key tool to prepare various heterocyclic derivatives with different properties by deploying several functional groups and creating numerous carbon-carbon, and carbon-heteroatom linkages. Over several years MCRs get significant attention due to easy process, efficient to produce a good yield, and cost-effectiveness. Indoles (Fig. 1), imidazoles, thazines, pyrroles, quinolones, and pyridine derivatives are pharmacologically interesting heterocycles which show biological activity and antimicrobial activity [2].

Indole derivatives have attracted attention over a few decades, because of many activities such as antimicrobials [3], pharmacological, anti-fungals [4], and anti-tumor [5], anti-inflammatories, antivirals [6], antibiotics drugs [7], and anticancer [8] (Fig. 2). Recently, Arvelexin (a 3-substituted indole derivative) is used as an anti-influenza agent. Hien T. Le and co-workers demonstrate indole-3carbinol having activity against human protease cancer cells. Some indole derivatives work as antioxidant agent through trapping free radicals and reduce the risk of cancer and cardiovascular diseases.

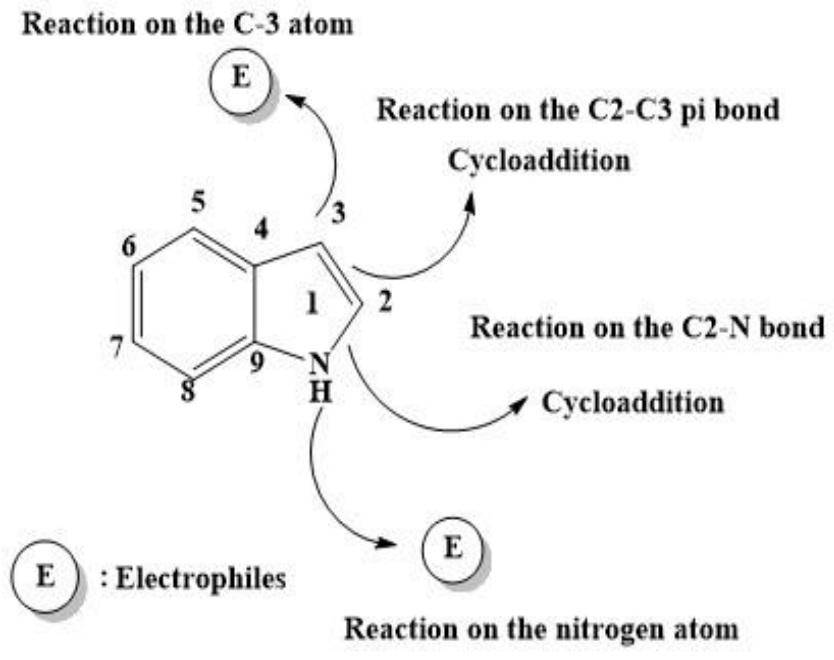

(a)

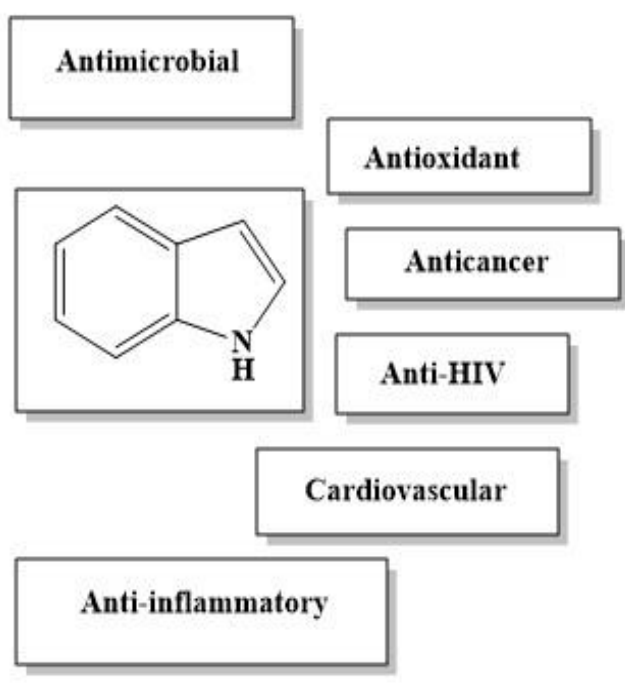

(b)

Figure 1. a) Reactive sites of Indole and b) Bio-activity of indole derivatives

In this study we addressed recent developments in organic synthesis methodology for multicomponent reactions for the preparation of substituted indole derivatives with a more environmentally friendly metal free catalysis, as well as their corresponding applications in recent 
decades. The rate of substitution is highest at C-3 position, followed by N-position to produce Nsubstituted indole and it is least at C-2 position.

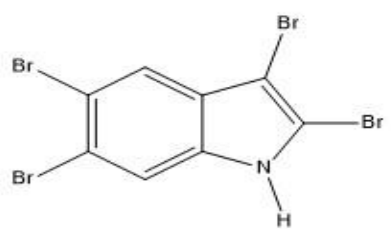

2,3,5,6-tetrabromo indole

(Antimicrobial)

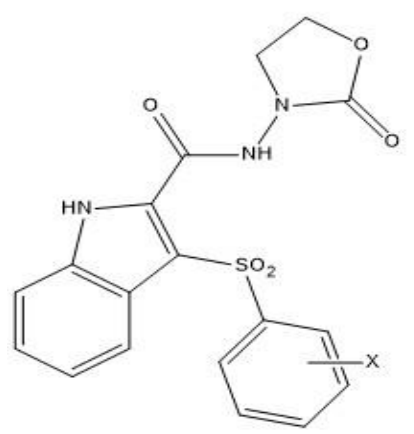

$(\mathbf{X}=\mathbf{H}, \mathbf{M e})$

Indolyl aryl sulfones as anti-HIV agent

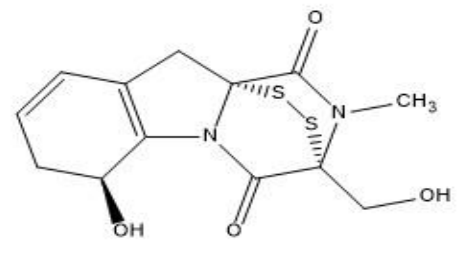

Gliotoxin

(Antibiotic)

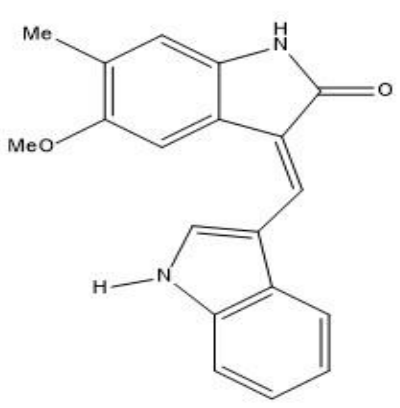

(Antitumor)

(E)-3((1H-indol-3-yl)methylene)5-methoxy-6-methylindolin-2-one

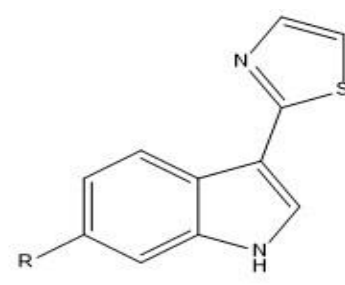

Camalexin

( R= H, OH, O-hex, O-hex-malonyl) (Antifungal)

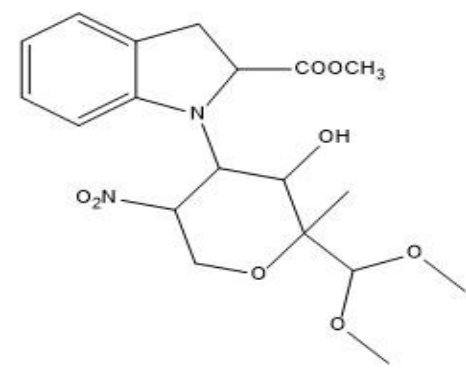

(R= Me,Et, iPr)

Compounds with cardiovascular activity

Figure 2. Example of some biologically active indole derivatives

This review focuses mainly on the reactivity at C-3 sites of indole as well as the corresponding properties of products in detail. Few miscellaneous multi-component reactions with indole have also been reviewed.

\section{Methods for Preparation of Indole Derivatives}

A variety of methods have been established to successfully production of a library of indole derivatives using metal-catalyzed reactions, multi-component synthesis, microwave synthesis, ultrasonication method, etc. Among them most feasible metal-free multi-component synthesis is our main interest.

\section{Brief Review on Multicomponent Reactions of Indoles}

Multi-component reaction (MCR) is a process where three (e.g. Passerini reaction) or more than three (e.g. four component Ugi reaction) components are used in a suitable solvent for a single reaction to obtain an ultimate substrate proposing superior opportunities or potentials for molecular diversity 
with greater efficiency of reactions and reduction of time, effort and cost. Indole containing one benzene ring and one five-membered pyrrole type moiety can easily participate in multi-component reactions, by reactions through its various reactive sites. Indole undergoes substitution reactions at the N1, C2, and $\mathrm{C} 3$ sites, as well as cycloaddition reactions via the $\mathrm{C} 2-\mathrm{C} 3$ and $\mathrm{C} 2-\mathrm{N}$ sigma bonds.

\section{Multicomponent Reactions at the C-3 Position}

Bhattacharjee and co-workers [10] have introduced ammonium chloride for the synthesis of 9(1H-indol-3-yl)-3,3-dimethyl-2,3,4,9-tetrahydro-1H-xanthen-1-one as a catalyst for the one-pot threecomponent synthesis of indole with aldehyde(o-hydroxy) and dimedone(1,3-dione) compounds (Scheme1). Ganguly et al. [11] re-investigated the same procedure, in which L-proline was used as a catalyst in an aqueous solvent for 2 hours.
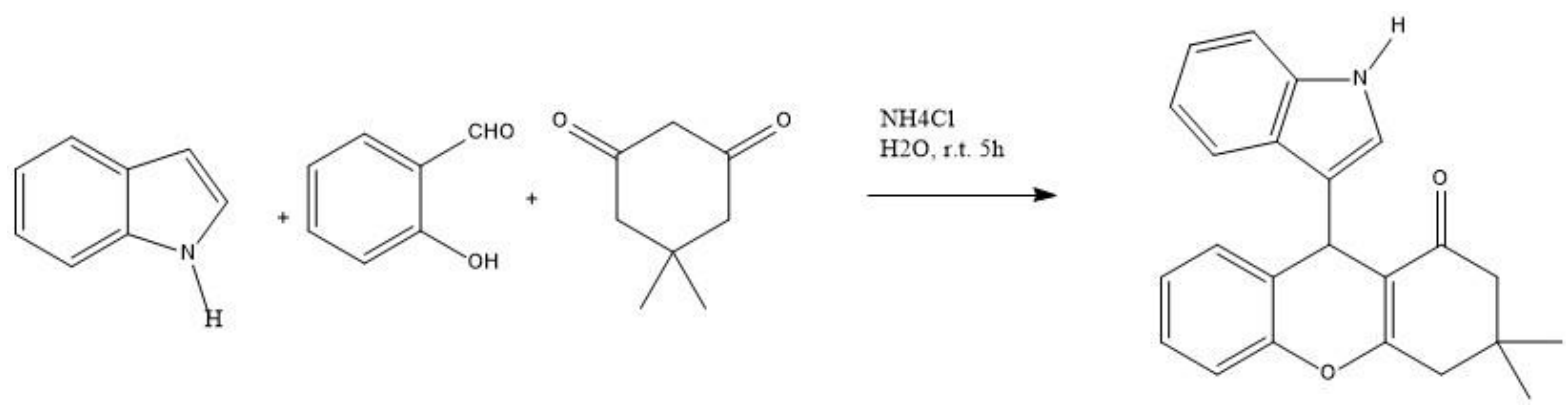

Scheme 1. Represents the indole (three-component) reaction, which consists of indole, salisaldehyde, and dimedone [11]

Jiang and Yan [12] achieved the synthesis of 3-substituted indole using a one-pot threecomponent reaction. They synthesized 3-1-[2-(1H-indol-3-yl)ethyl]-4,5,6,7-tetrahydro-1H-indol-3ylindolin-2-ones by condensation of 2-(1H-indol-3-yl) ethanamine with 3-phenacylidene oxindoles and dimedone in acetonitrile under refluxing conditions with p-toluene sulfonic acid catalyst (Scheme 2).

Klenc et al. [13] and Fatma et al. [14] have demonstrated an efficient synthetic route for indol3-yl substituted with pyran derivatives using ultrasonic irradiation and a reaction with piperidine activity as a catalyst. A sharp enhancement of yield was observed for the same reaction in presence of cetyltrimethylammonium bromide $(\mathrm{CTAB})$ and thiamine hydrochloride (vitamin $\mathrm{B} 1$ ) as catalyst (Scheme 3).

The earlier method (1-pot 3-component) condensation was introduced for the synthesis of indole-based tetra-arylimidazoles by Naureen's group [16]. In this approach 2-arylindole-3carbaldehydes are reacted with aniline and benzyl in the presence ammonium acetate and acetic acid (Scheme 5). The synthesized compounds has shown anti-urease activity. 


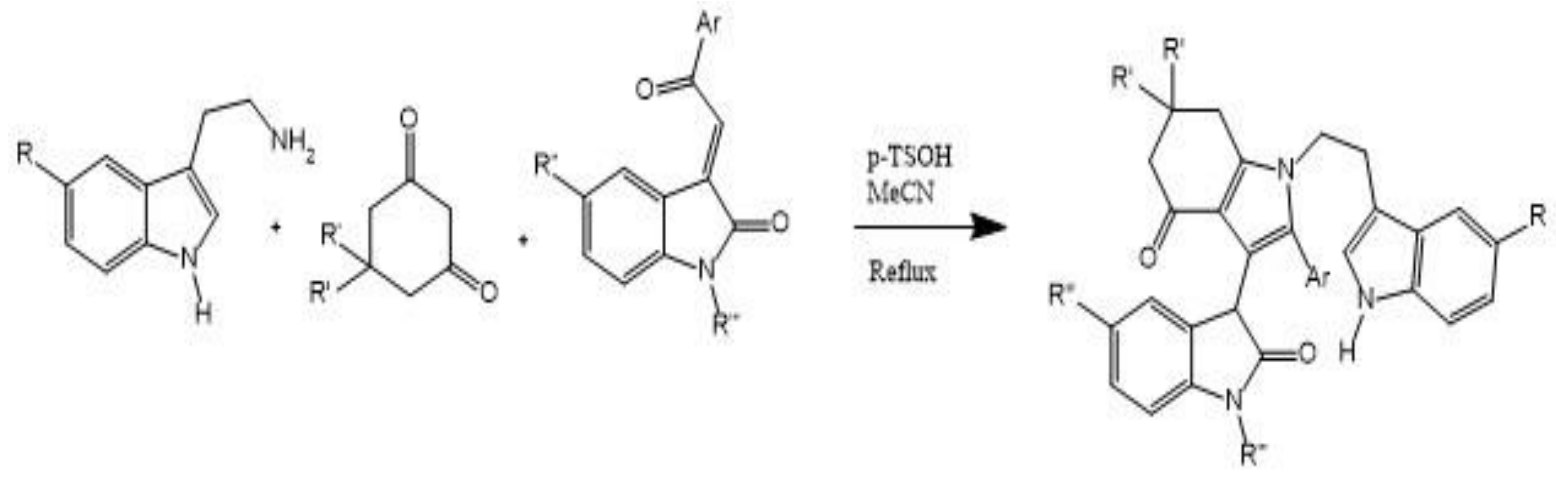

$\mathrm{R}^{1}=\mathrm{H}, \mathrm{OMe} ; \mathrm{R}^{2}=\mathrm{H}, \mathrm{Cl}, \mathrm{F}, \mathrm{Me} ; \mathrm{R}^{3}=\mathrm{H}, \mathrm{Bn} ; \mathrm{Ar}=\mathrm{Ph}, 4-\mathrm{ClC}_{6} \mathrm{H}_{4}, 4-\mathrm{OMeC}_{6} \mathrm{H}_{4} ; \mathrm{p}-\mathrm{TsOH}: \mathrm{p}-$ Toluenesulfonic acid

Scheme 2. Synthesis of three components of 3-\{1-[2-(1H-indol-3-yl)ethyl]-4,5,6,7-tetrahydro- $1 \mathrm{H}-$ indol-3- yl \}indolin-2-ones [12]
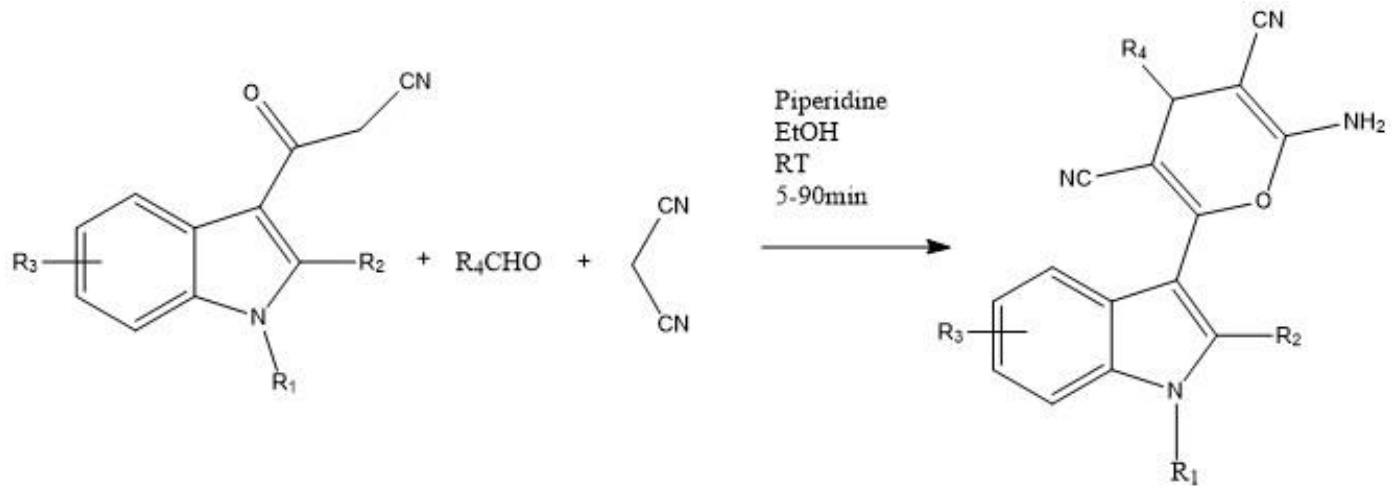

$\mathrm{R}^{1}=\mathrm{H}, \mathrm{Me} ; \mathrm{R}^{2}=\mathrm{H}, \mathrm{Ph} ; \mathrm{R}^{3}=5-\mathrm{Br}, 7-\mathrm{Me} ; \mathrm{R}^{4}=\mathrm{Ph}, 4-\mathrm{MeC}_{6} \mathrm{H}_{4}, 4-\mathrm{MeOC}_{6} \mathrm{H}_{4}, 2,4-\mathrm{Cl}_{2} \mathrm{C}_{6} \mathrm{H}_{3}, 2-\mathrm{BrC}_{6} \mathrm{H}_{4}, 3-\mathrm{NO}_{2} \mathrm{C}_{6} \mathrm{H}_{4}, 4-\mathrm{NO}_{2} \mathrm{C}_{6} \mathrm{H}_{4}$, 2-Naphthyl

Scheme 3. Synthesis of indole derivatives(3-substituted compounds) [14]<smiles></smiles>

Scheme 4. Multi-component condensation reactions (one-pot) of aromatic aldehydes, ethyl cyanoacetate, 3-acetylindole and ammonium acetate using piperidine as catalyst [15] 


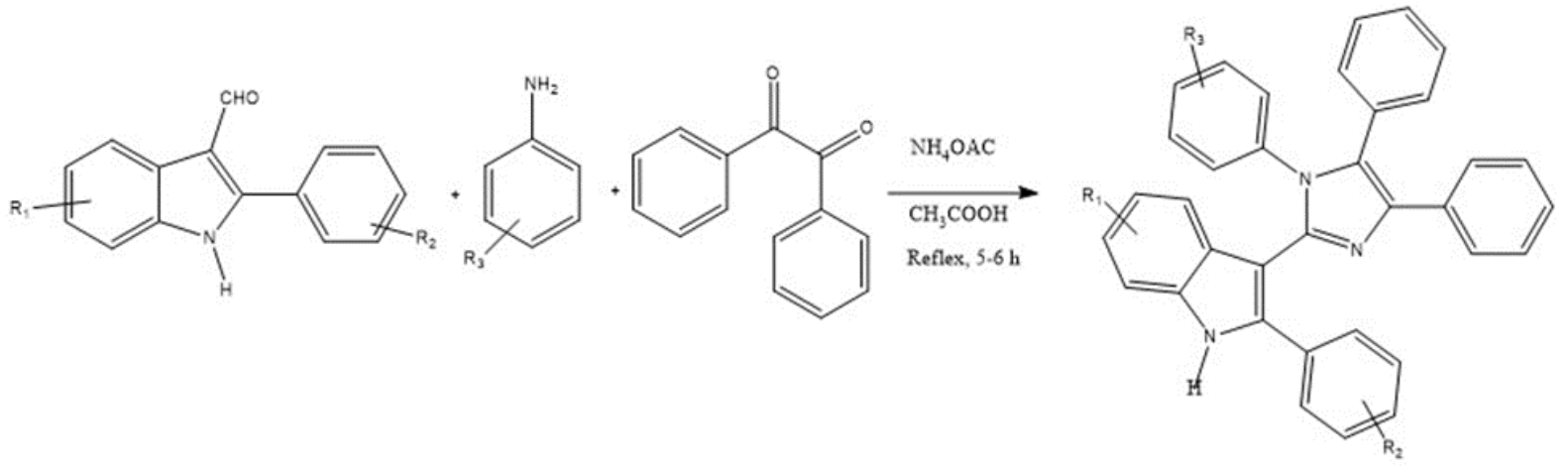

$\mathrm{R}^{1}=\mathrm{H}, 5-\mathrm{Br} ; \mathrm{R}^{2}=\mathrm{H}, 4-\mathrm{Cl}, 4-\mathrm{CF}_{3} ; \mathrm{R}^{3}=\mathrm{H}, 4-\mathrm{Me}, 4-\mathrm{OMe}, 3-\mathrm{F}, 4-\mathrm{Cl}, 4-\mathrm{Br}$

Scheme 5. Reaction of 2-arylindole-3-carbaldehydes with substituted anilines and benzyl in the presence of ammonium acetate and acetic acid [16]

Chen et al. [17] prepared a variety of C-3 substituted compounds, including polysubstituted 6'(1H-indol-3-yl) -1',7'-dihydrospiro[indoline-3,4'pyrazolo[3,4-b]pyridine]-2-one derivatives in acetic acid/water using a simple atom-saving method involving a one-pot three-component condensation reaction (Scheme 6).
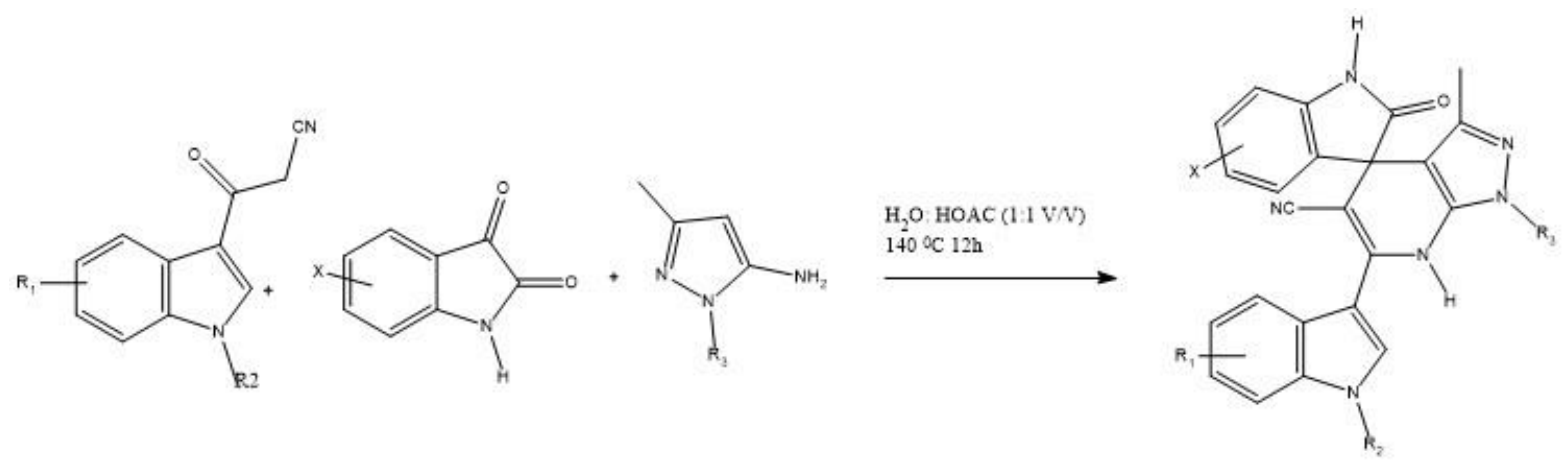

$\mathrm{R}^{1}=\mathrm{H}, 6-\mathrm{CH}_{3} ; \mathrm{R}^{2}=\mathrm{H}, \mathrm{CH}_{3} ; \mathrm{R}^{3}=\mathrm{Ph}, \mathrm{CH}_{3} ; \mathrm{X}=5-\mathrm{Br}, 6-\mathrm{Br}, \mathrm{H}$

Scheme 6. A three-component one-pot reaction of involving 3-cyanoacetyl indoles, isatins, and 1H-pyrazol-5-amines in $\mathrm{H} 2 \mathrm{O} / \mathrm{HOAc}$ [17]

Indole, acenaphthylene-1,2-dione, and enaminone were combined in a one-pot three-component reaction in the presence of piperidine and p-TSA as catalyst to produce indole derivatives (Scheme 7) [18].

Borpatra et al. [19] have synthesized a one-pot 3-component indole derivatives in the presence of base catalysts with the reaction of indole and benzaldehyde at room temperature and sodium hydroxide in EtOH-H2O as solvent after the reaction formation of 3-indolylalcohols (Scheme 8). To obtain the desired product in its purest form, the material was purified using column chromatography. 
Fawzy et al. [20] synthesized some indole derivatives by the reaction of 1H-indole-3carbaldehyde, aniline derivatives and malononitrile ethanol using triethylamine as a catalyst. The mixture was continuously stirred. Using thin-layer chromatography, the reaction's progress was tracked, and a precipitate was developed. The pure products were obtained by filtering the precipitate, washing with ethanol, and drying (Scheme 9).<smiles>[R]NC1=CC(=O)CC(Br)(Br)C1</smiles><smiles>c1ccc2[nH]ccc2c1</smiles><smiles>O=C1C(=O)c2cccc3cccc1c23</smiles>
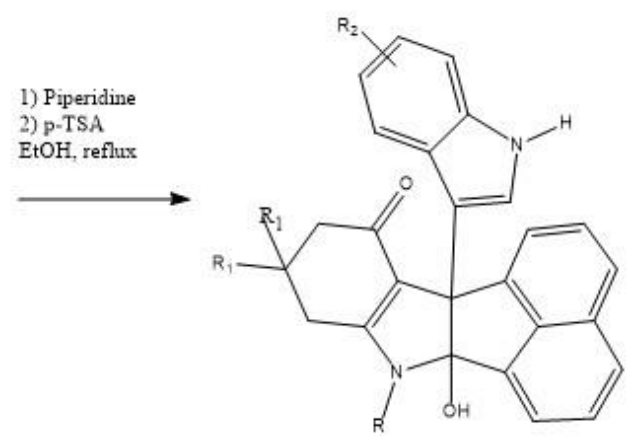

Scheme 7. Synthesis of bis-indoles [18]<smiles>c1ccc2[nH]ccc2c1</smiles><smiles>[R]c1cccc(C=O)c1</smiles>

$+\quad \mathrm{NuH}$

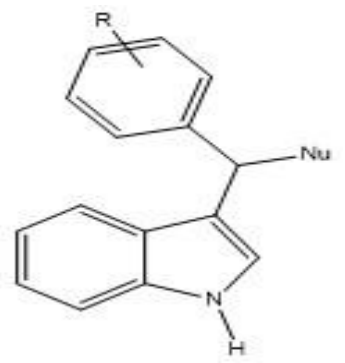

Scheme 8. Represents a three-component reaction synthesis of 3- substituted indole derivatives [19]<smiles>CN1CC(O)c2ccccc21</smiles><smiles>Nc1ccc(Br)c(Br)c1Br</smiles>

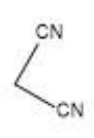<smiles>CCOCC</smiles><smiles>Cc1c(-c2cn(C)c3ccccc23)nc2c([18F])c(Br)c(Br)cc2c1N</smiles>

Scheme 9. Represents a three component reactionof indole derivatives [20]

Wang et al. [21] were performed bicyclization reaction method to produce a catalyst free product called oxazolo[5,4-b]indoles by using microwave-assisted three-component. The reaction conditions 
include: arylglyoxal (2.0 mmol, 2.0 equiv), cyclic enaminone (1.0 mmol, 1.0 equiv), alanine (1.0 mmol, 1.0 equiv), solvent ( $2.0 \mathrm{~mL})$, air, and microwave heating (Scheme 10).<smiles>O=C(O)C(O)CO</smiles><smiles>CC1(C)CC(=O)C=C(Nc2ccccc2)C1</smiles>
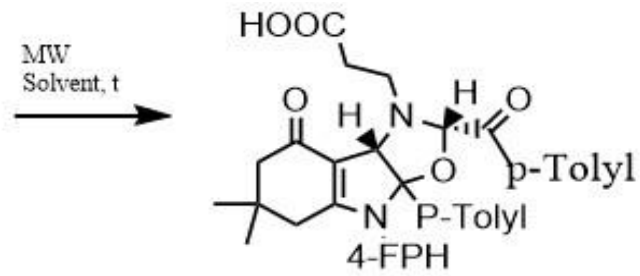

Scheme 10. A microwave-assisted three-component bicyclization [21]

Lin et al. [22] used aniline ( $1 \mathrm{mmol})$, arylglyoxal monohydrate (1 mmol), cyclic 1,3-dicarbonyl compound $(1 \mathrm{mmol})$, and $\mathrm{CF} 3 \mathrm{COOH}(0.2 \mathrm{mmol})$ to make indoles under microwave irradiation. They combined all the compounds in a $10 \mathrm{ml}$ initiator reactor vial, followed by ethanol $(2 \mathrm{ml})$, and water ( 2 $\mathrm{ml})$. After that, the reaction was close-up, pre-stirred for 10 seconds, and microwave-irradiated for 40 minutes at $90{ }^{\circ} \mathrm{C}$ (Scheme 11). Thin-layer chromatography was used to track the reaction (3:1 ratio mixture of petroleum ether and ethyl acetate). The reaction mixture was cool to room temperature until the solvent was vaporised at a low pressure. The crude product was purified using column chromatography with petroleum ether and ethyl acetate as eluents.
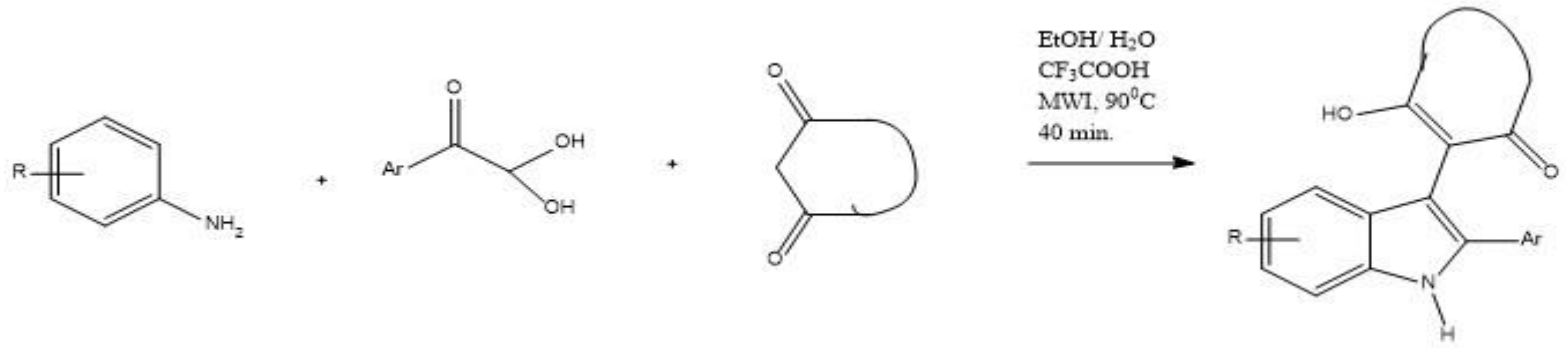

Scheme 11. Indole synthesis is based on a three-component reaction under microwave irradiation [22]

Zeng et al. [23] established a multi-component reaction for the synthesis of indole carboxamide amino amides using 4-nitrobenzaldehyde, aniline, indole-N-carboxylic acid, and benzyl isocyanide (Scheme 12).

Indole or N-methyl indole or substituted indole, aldehyde or substituted aldehyde, and malononitrile were reacted to form the novel 3-substituted indole, according to Singh et al. [24] catalyst free reaction presence of an electrolyte and ethanol as solvent. These environmentally friendly, electrochemical reaction procedure was simple, efficient and reaction condition were mild. This synthesis has therapeutic applications (Scheme 13).

The development of new methodologies for the synthesis of one-pot four- component rection of 3-(1H-indol-3-yl)-3-oxopropanenitrile, aldehydes, 3-acetyl-2H-chromenones, and ammonium acetate in 
acetic acid (Scheme 14). These reaction highly functionalized and advantages less reaction time under metal-free reaction condition [25].

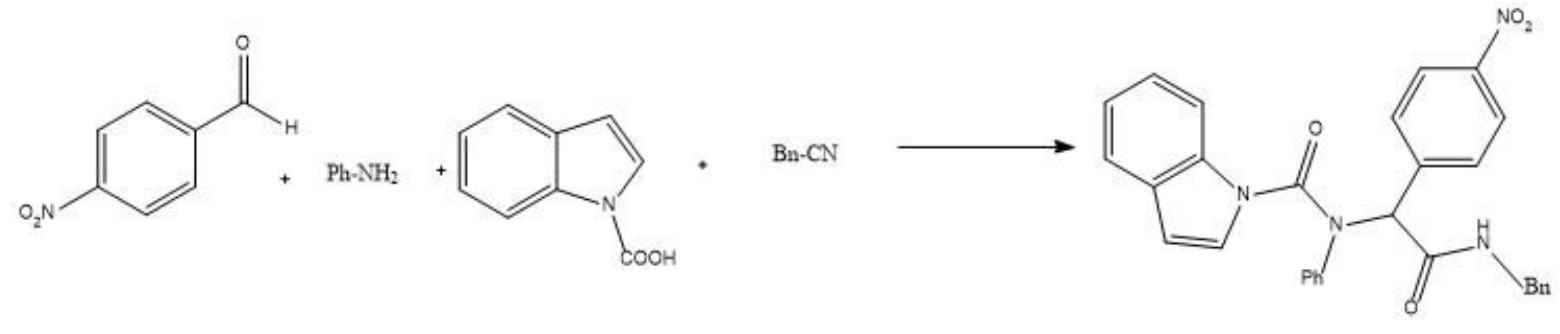

Scheme 12. Represent a four component chemical reaction [23]

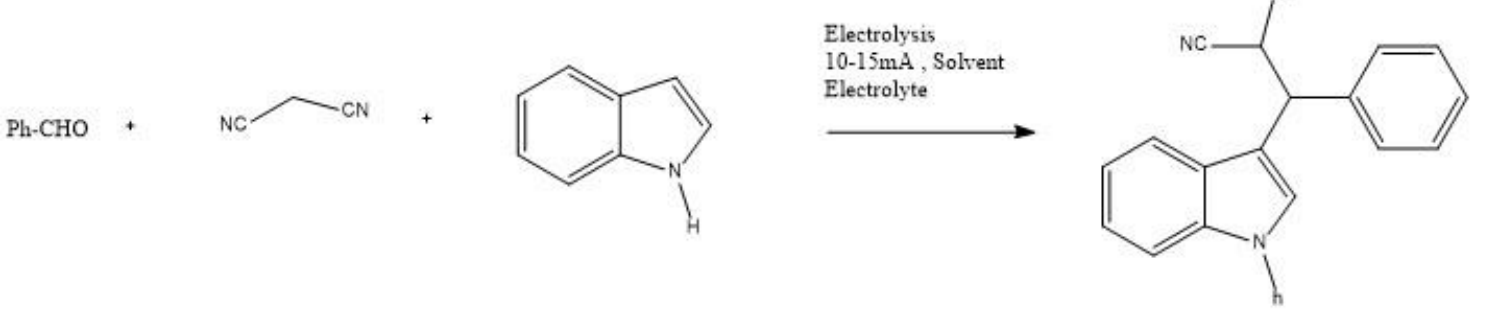

Solvent $=\mathrm{MeOH}, \mathrm{EtOH}, \mathrm{n}-\mathrm{PrOH}, \mathrm{CH}_{3} \mathrm{CN}$; Electrolyte $=\mathrm{LiClO}_{4}, \mathrm{NaBr}, \mathrm{KBr}, \mathrm{Bu}_{4} \mathrm{NClO}_{4}$

Scheme 13. Synthesis of 3-substituted indole in a three-component reaction [24]

$\sum_{-1}^{N}$

- $\prod_{H}$.<smiles>C=C(C)c1cc2ccccc2oc1=O</smiles>

$\mathrm{CH}_{3} \mathrm{COONH}_{4}$

Acetic acid
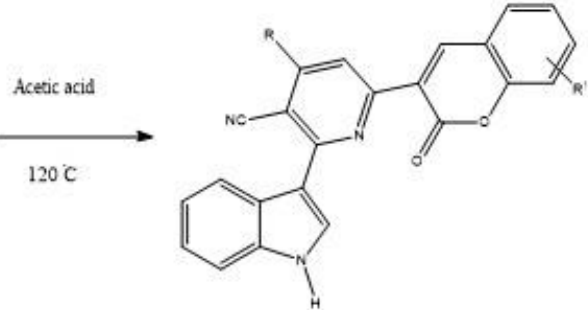

$\mathrm{R}=$ Aromatic, Heteroaromatic and Aliphatic: $\mathrm{R}^{1}=\mathrm{H}, \mathrm{Br}, \mathrm{OH}, \mathrm{N}(\mathrm{Me})_{2}, \mathrm{~N}(\mathrm{Et})_{2}, \mathrm{OMe}, \mathrm{OEt}$

Scheme 14. Represent a four component reaction [25]

Mazzotta et al. synthesized 3-amino-alkylated indoles by heating the mixture of indole and aldehydes with morpholine in ethylene glycole at $90^{\circ} \mathrm{C}$ for 1 hour, then cooling it at room temperature and filtering it under vacuum.To extract ethylene glycol, the rough solid was partitioned between chloroform and water.The eluent was N-hexane/ethyl acetate (3:1), which was then distilled using flash column chromatography (Scheme 15). In this region, indole derivatives have shown to be effective antiinflammatory agents [26]. 
The efficient and advantageous synthesis of indole in the presence of ethanol as a solvent react one-pot multi-component reaction of 2,5-disubstituted indole-3-carbaldehyde, isoniazid, and naphthalen-2-ol, quinolin-8-ol, or 4-hydroxy-2 H-chromen-2-one by Rathod et al. In vitro antitubercular activity was observed with these compounds [27] (Scheme 16).

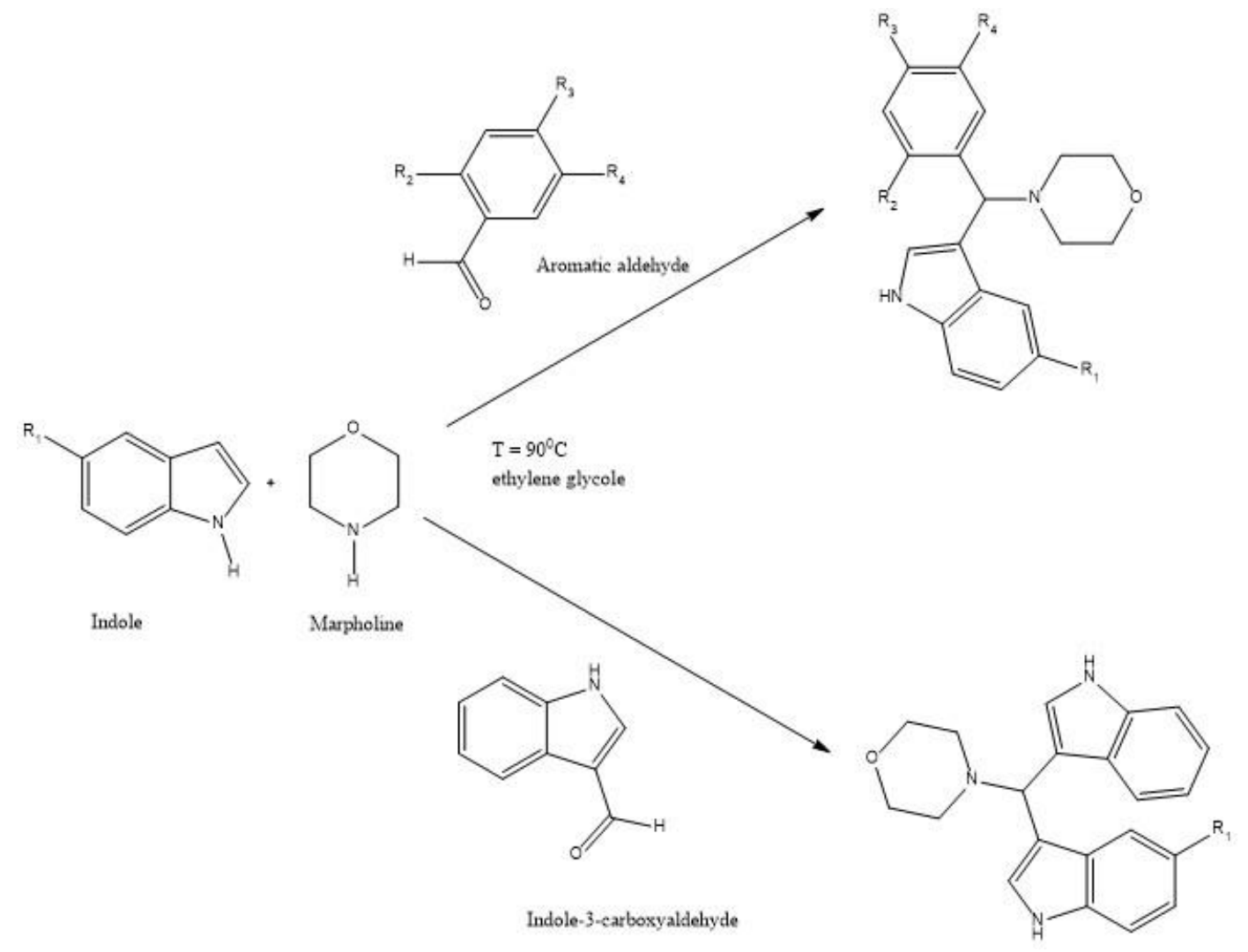

Scheme 15. Multi-component synthesis of GLYC compounds [26]

Dhuguru and Skouta [29] have developed an indole-chalcone derivative that binds to tubin and inhibits cancer cell development. In the presence of piperidine as a catalyst, the condensation reaction between the acetophenone derivative and the indole-3-carboxaldehyde yields FC77 (Scheme 18).

A domino reaction between arylglyoxals, acetylacetone, indole, and aliphatic amines in water without any catalyst was performed to produce a four-component one-pot synthesis of pyrrole functionalized indole derivatives by Mousavizadeh et al. [30] (Scheme 19).

Kumari et al. described the efficient synthesis of the carbohydrate related pyrazoline and isoxazole bridged C-glycoside (O-linkages) of indole hybrids identified a unsaturated-C-glyosidic ketone molecule that can be synthesised using C-glycoside as a substrate. The resulting-unsaturated-Cglyosidic ketone molecule can then be nucleophilically added to hydrazine hydrate/hydroxyl amines at room temperature or at elevated temperatures, and transformed into the desired pyrazoline or isoxazole bridged C-glycoside of indole by dehydration [31] (Scheme 20). 
Yang and Li et al. [32] synthesized indole derivatives in the presence of potassium hydroxide, benzylidene malononitrile (Scheme 21). The benzylidene malononitrile reacts with indole at inert N2 gas, product by micheal addition was obtained in $65 \%$ yield, and the oxidative cross-coupling product were detected in traces. Moreover, michael addition product was readily converted into cross-couping product in high yield under the standard conditions. This meant that the michael addition product may be a potential intermediate in the reaction of malononitrile with indole to produce cross-couping product, and that air is needed for its formation. In the presence of potassium hydroxide, these intermediates are dehydrated, yielding cross-couping product as the final product [32].

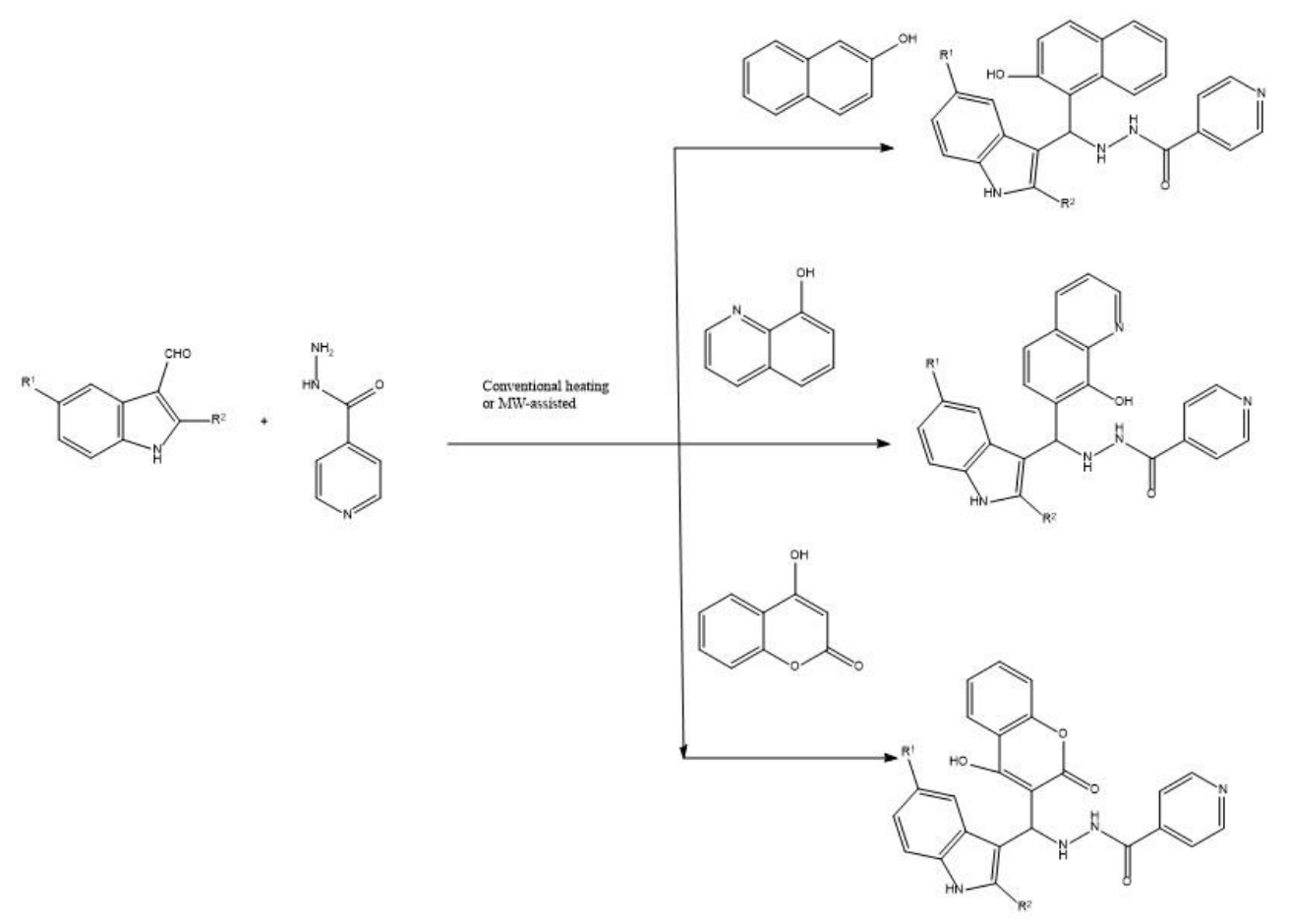

Scheme 16. The indole and isoniazid derivatives were synthesised with the aid of microwaves [27]

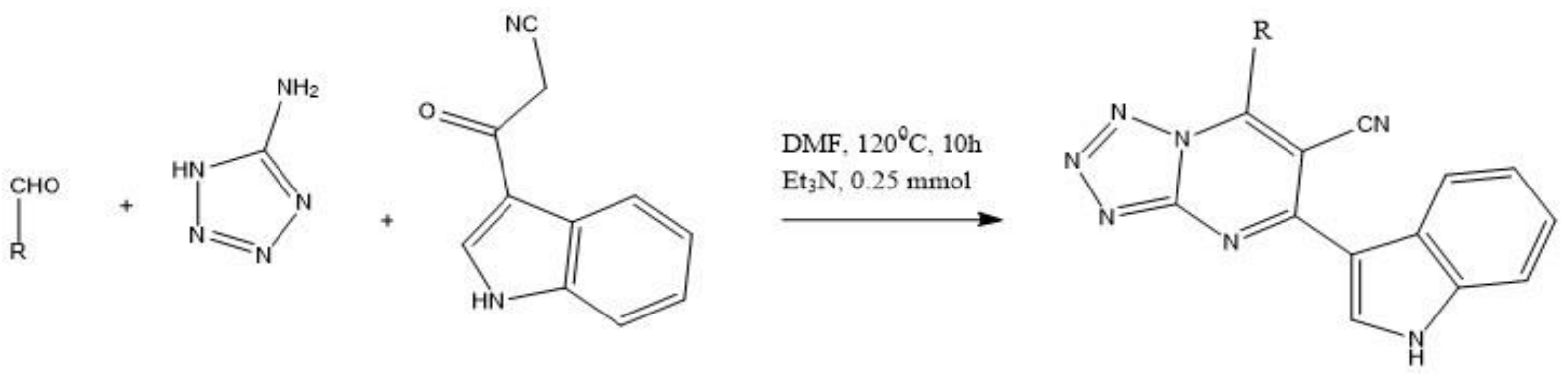

Scheme 17. Synthesis of novel 7-substituted-5-(1H-Indol-3yl)tetrazolo[1,5-a]pyrimidine-6carbonitrile in a three-component reaction [28] 
<smiles>CCC(=O)c1cc(C)c(C)c(O)c1</smiles><smiles>O=Cc1c[nH]c2ccccc12</smiles><smiles>COc1cc(C(=O)C(C)=Cc2c[nH]c3ccccc23)cc(C)c1C(N)=O</smiles>

Scheme 18. An indole-chalcone derivative is synthesised in the presence of piperidine as a catalyst [29]<smiles>CC(=O)CC(C)=O</smiles>

Scheme 19. The reaction of arylglyoxals, acetylacetone, indole, and aliphatic amines yields indolylpyrrole derivatives [30]
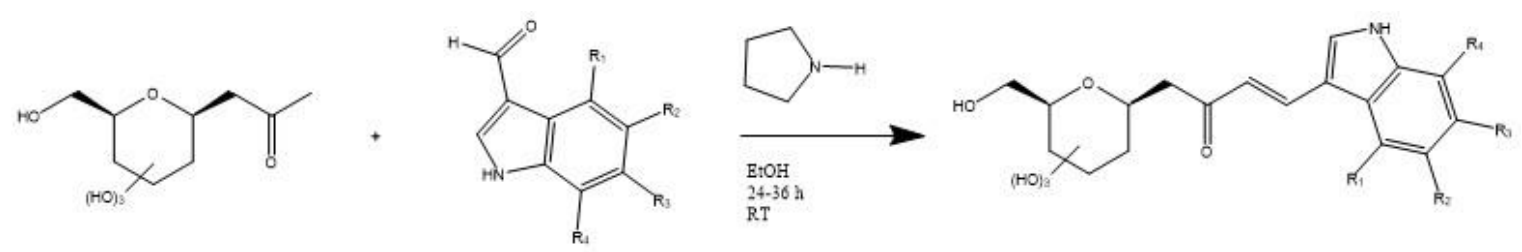

Scheme 20. Synthesis of various indole C-glycosides [31]

In conclusion, this review encapsulates recent signs of progress in the synthesis of pharmaceutically significant indole heterocyclic skeletons. Here we count simple, cheap, atomically efficient, less time and effort consumable processes with metal-free organic acid/base catalyzed synthesis of highly functionalized indoles. From the last few decades, a heterocyclic compound with indole linkage has gained significant importance in medicinal, natural product chemistry, and pharmaceutical industries. In all of the above mentioned one pot multi-component reactions indicates a large potential for the synthesis of biologically beneficial molecules, through $\mathrm{C}-\mathrm{H}$ activation and condensation reactions. Our review provides an overview of the plausible synthetic procedure of indole derivative that can help for deciding the future strategy for the preparation of a library of indole derivatives with medicinal importance. 
<smiles>N#C/C(Cl)=C\c1ccccc1</smiles>

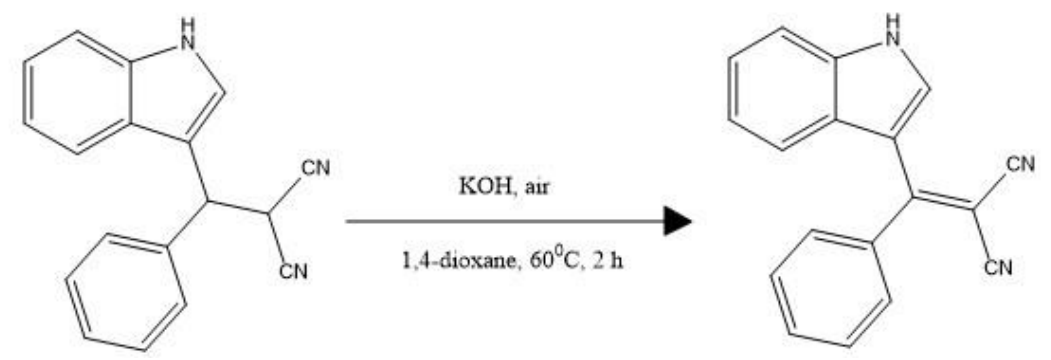

Scheme 21. Synthesis of indole- functionalized arylidenemalononitriles [32]

\section{ACKNOWLEDGEMENT}

The authors are thankful to the Head of the Department of chemistry Dr. Harisingh Gour Central University, Sagar (MP), India, for providing laboratory facilities and CSIR Delhi India for giving NETJRF fellowship grant.

\section{AUTHOR CONTRIBUTIONS}

Conception: R.D.; Design: H.D., R.D.; Supervision: R.D.; Resources: R.D., S.K.; Materials: H.D., R.D.; Data collection and/or processing: H.D.; Analysis and/or interpretation: H.D., R.D.; Literature search: H.D., R.D., S.K.; Writing manuscript: H.D., R.D.; Critical review: H.D., R.D.; Other:-

\section{CONFLICT OF INTEREST}

The authors declare no conflict of interest.

\section{REFERENCES}

1. Yellappa, S. (2020). An anti-Michael route for the synthesis of indole-spiro (indene-pyrrolidine) by 1,3-cycloaddition of azomethineylide with indole-derivatised olefins. Journal of Heterocyclic Chemistry, 57, 1083-1089. [CrossRef] 
2. Tha, S., Shakya, S., Malla, R., Aryal, P. (2020) Prospects of Indole derivatives as methyl transfer inhibitors: Antimicrobial resistance managers. BMC Pharmacology Toxicology, 21, 1-11. [CrossRef]

3. Sayed, M., Younis, O., Hassanien, R., Ahmed, M., Mohammed, A.A.K., Kamal, A.M., Tsutsumi, O. (2019). Design and synthesis of novel indole derivatives with aggregation-induced emission and antimicrobial activity. Journal of Photochemistry and Photobiology A: Chemistry, 383, 111969. [CrossRef]

4. Parle, A., Kumar, N. (2020). Synthesis, characterization and evaluation of 3- acetylindole derivatives as potential antifungal agents. 9(6), 468-474. Retrieved from https://www.thepharmajournal.com/archives/?year=2020\&vol=9\&issue $=6 \&$ ArticleId $=4808$

5. Mo, Z.-Y., Wang, X.-Y., Zhang, Y.-Z., Yang, L., Tang, H.-T., Pan, Y.-M. (2020). Electrochemically enabled functionalization of indoles or anilines for the synthesis of hexafluoroisopropoxy indole and aniline derivatives. Organic \& Biomolecular Chemistry, 18, 3832-3837. [CrossRef]

6. Wei, C., Zhao, L., Sun, Z., Hu, D., Song, B. (2020). Discovery of novel indole derivatives containing dithioacetal as potential antiviral agents for plants. Pesticide Biochemistry and Physiology, 166, 104568. [CrossRef]

7. Turner, D.N., Edwards, L., Kornienko, A., Frolova, L.V., Rogelj, S. (2020). Synergistic action of substituted indole derivatives and clinically used antibiotics against drug-resistant bacteria. Future Microbiology, 15(8), 579-590. [CrossRef]

8. Syahri, J., Hidayah, N., Hilma, R., Nurohmah, B.A. (2020). Design of new 2,4-substituted furo [3,2-b]indole derivatives as anticancer compounds using quantitative structure-activity relationship (QSAR) and molecular docking. Molekul, 15(1), 9 - 17. [CrossRef]

9. Zeng, L., Lin, Y., Cui, S. (2020). Indole-N-carboxylic acids and indole-N-carboxamides in organic synthesis. Chemistry-An Asian Journal, 15, 973-985. [CrossRef]

10. Bhattacharjee, S., Das, D.K., Khan, A.T. (2014). Ammonium chloride-catalyzed threecomponent reaction for the synthesis of fused $4 \mathrm{H}$-chromene derivatives in aqueous medium. Synthesis, 46, 73-80. [CrossRef]

11. Ganguly, N.C., Roy, S., Mondal, P., Saha, R. (2012). An efficient one-pot organocatalytic synthesis of 9-(1H-indol-3-yl)-xanthen-4-(9H)-ones under mild aqueous micellar conditions. Tetrahedron Letters, 53, 7067-7071. [CrossRef]

12. Jiang, Y.H., Yan, C.G. (2016). Three-component reaction for the convenient synthesis of functionalized 3-\{1-[2-(1H-indol-3-yl)ethyl]-4,5,6,7-tetrahydro-1H-indol-3-yl $\}$ indolin-2-ones. Synthesis, 48, 3057-3064. [CrossRef]

13. Klenc, J., Saczewski, J., Paluchowska, A., Raux, E. (2009). Synthesis of 4-substituted 2-(4methylpiperazino)pyrimidines and quinazoline analogs as serotonin 5-HT 2A receptor ligands. Journal of Heterocyclic Chemistry, 46, 1259-1265. [CrossRef]

14. Fatma, S., Singh, D., Ankit, P., Mishra, P., Singh, M., Singh, J. (2014). An eco-compatible multicomponent strategy for the synthesis of new 2-amino-6-(1H-indol-3-yl)-4-arylpyridine3,5-dicarbonitriles in aqueous micellar medium promoted by thiamine-hydrochloride. 
Tetrahedron Letters, 55, 2201-2207. [CrossRef]

15. El-Sayed, N.S., Shirazi, A.N., El-Meligy, M.G., El-Ziaty, A.K., Rowley, D., Sun, J., Nagib, Z.A., Parang, K. (2014). Synthesis of 4-aryl-6-indolylpyridine-3-carbonitriles and evaluation of their antiproliferative activity. Tetrahedron Letters, 55, 1154-1158. [CrossRef]

16. Naureen, S., Ijaz, F., Munawar, A.M., Asif, N., Chaudhry, F., Ashraf, M., Khan, M.A. (2017). Synthesis of tetrasubstitutd imidazoles containing indole and their antiurease and antioxidant activities. Journal of the Chilean Chemical Society, 62, 3583-3587. [CrossRef]

17. Chen, T., Xu, X.P., Ji, S.J. (2010). Novel, one-pot, three-component route to indol-3-yl substituted spirooxindole derivatives. Journal of Combinatorial Chemistry, 12, 659-663. [CrossRef]

18. Chen, X.B., Xiong, S.L., Xie, Z.X., Wang, Y.C., Liu, W. (2019). Three-component one-pot synthesis of highly functionalized bis-indole derivatives. ACS Omega, 4, 11832-11837. [CrossRef]

19. Borpatra, P.J., Deka, B., Rajbongshi, B.K., Deb, M.L., Baruah, P.K. (2018). One-pot sequential multi-component reaction: Synthesis of 3-substituted indoles. Synthetic Communications, 48, 2074-2082. [CrossRef]

20. Fawzy, N.M., Roaiah, H.M., Awad, E.M., Wietrzyk, J., Milczarek, M., Soliman, A.M.M. (2018) Synthesis of new indole derivatives using one- pot multicomponent reaction with antiproliferative towards normal and cancer cell lines. Egyptian Pharmaceutical Journal, 17(2), 1687-4315 [CrossRef]

21. Wang, L. Shi, L.-X., Lu, L., Li, Z.-X., Xu, T.W., Hao, J., Li, G., Tu, S.-J., Jiang, B. (2017). Synthesis of diastereoenriched oxazolo[5,4-b]indoles via catalyst-free multicomponent bicyclizations. Journal of Organic Chemistry, 82, 3605-3611. [CrossRef]

22. Lin, W., Zheng, Y.X., Xun, Z., Huang, Z.B., Shi, D.Q. (2017). Microwave-assisted regioselective synthesis of 3-functionalized indole derivatives via three-component domino reaction. ACS Combinatorial Science, 19, 708-713. [CrossRef]

23. Zeng, L., Sajiki, H., Cui, S. (2019). Multicomponent ugi reaction of indole- n-carboxylic acids: expeditious access to indole carboxamide amino amides. Organic Letters, 21, 5269-5272. [CrossRef]

24. Singh, V.K., Dubey, R., Upadhyay, A., Sharma, L.K., Singh, R.K.P. (2017). Electrochemical approach for synthesis of 3-substituted indole derivatives. Tetrahedron Letters, 58, 4227-4231. [CrossRef]

25. Krishnammagari, S.K., Balwe, S.G., Kim, J.S., Lim, K.T., Jeong, Y.T. (2019). A one-pot fourcomponent domino protocol for the synthesis of indole and coumarin containing pyridine-3carbonitrile derivatives. Monatshefte fur Chemie, 150, 691-702. [CrossRef]

26. Mazzotta, S., Frattaruolo, L., Brindisi, M., Ulivieri, C., Francesca, V., Brizzi, A., Carullo, G., Cappello, A.R., Aiello, F. (2019). 3-Amino-alkylated indoles: Unexplored green products acting as anti-inflammatory agents. Future Medicinal Chemistry, 12, 5-17. [CrossRef]

27. Rathod, A.S., Reddy, P.V., Biradar, J.S. (2020). Microwave-assisted synthesis of some indole and isoniazid derivatives as antitubercular agents and molecular docking study. Russian Journal 
of Organic Chemistry, 56, 662-670. [CrossRef]

28. Radwan, M.A.A., Alminderej, F.M., Awad, H.M. (2020). One-pot multicomponent synthesis and cytotoxic evaluation of novel 7-substituted-5-(1H-indol-3yl)tetrazolo[1,5-a] pyrimidine-6carbonitrile. Molecules, 25, 255. [CrossRef]

29. Dhuguru, J., Skouta, R. (2020). Role of indole scaffolds as pharmacophores in the development of anti-lung cancer agents. Molecules, 25, 1615. [CrossRef]

30. Mousavizadeh, F., Talebizadeh, M., Anary-Abbasinejad, M. (2018). Synthesis of new indolylpyrrole derivatives via a four-component domino reaction between arylglyoxals, acetylacetone, indole and aliphatic amines in aqueous media. Tetrahedron Letters, 59, 29702974. [CrossRef]

31. Kumari, P., Mishra, V.S., Narayana, C., Khanna, A., Chakrabarty, A., Sagar, R. (2020). Design and efficient synthesis of pyrazoline and isoxazole bridged indole C-glycoside hybrids as potential anticancer agents. Scientific Reports, 10, 6660. [CrossRef]

32. Yang, A., Li, Z. (2020). Transition-metal-free aerobic oxidative cross-coupling of indoles with arylidenemalononitriles. Synlett, 31, 194-198. [CrossRef] 